Available online on 15.04.2020 at http://jddtonline.info
Open Access to Pharmaceutical and Medical Research
unrestricted non-commercial use, provided the original work is properly cited

Open $\odot$ Access

Research Article

\title{
Relation between BMI and Semen parameters in male infertility patients in west of Algeria
}

\author{
Ferrag Dalila, Demmouche Abbassia, Zine Charaf Khalloua \\ Biotoxicology Laboratory, Department of Biology. Faculty of Naturel Science and life. Djillali Liabes University; Sidi Bel Abbes. Algeria
}

\begin{abstract}
Introduction: Body mass index BMI is a risk factor that influences semen quality and reduces male fertility. The aim of this study was to determine the impact of body mass index (BMI) on semen parameters in infertile men.

Subject and method: A total of 446 infertile men, the study population was divided into four groups depending on their BMI , underweight ( $<18.5 \mathrm{~kg} /$ ), normal weight (18.5-24.99 kg/m2 ), overweight $25-29.99 \mathrm{~kg} / \mathrm{m} 2)$, and obese $>30.0 \mathrm{~kg} / . \mathrm{semen}$ parameters (PH, volume, concentration ,total semen count, vitality, morphology and motility) were compared across the four BMI groups.
\end{abstract}

Results: The mean of age was $41.91 \pm 6.39$, the mean infertility duration was $4.92 \pm 3.28,351(78.7 \%$ ) had primary infertility and $95(21.3 \%)$ had secondary infertility. The mean BMI was $29.38 \pm 4.85$ and the most of patients $45.2 \%$ were obese.

Conclusion: This study has found evidence of an association between BMI and semen parameters (Sperm concentration, Total sperm count, motility, and vitality) and no correlation between Semen volume, morphology and BMI.

Keywords: Body mass index, male infertility, semen quality, west of Algeria

Article Info: Received 03 Feb 2020; Review Completed 20 March 2020; Accepted 29 March 2020; Available online 15 April 2020

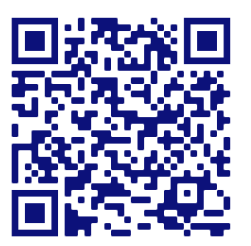

Cite this article as:

Ferrag D, Demmouche A, Zine CK, Relation between BMI and Semen parameters in male infertility patients in west of Algeria, Journal of Drug Delivery and Therapeutics. 2020; 10(2-s):64-67 http://dx.doi.org/10.22270/jddt.v10i2-s.4021

*Address for Correspondence:

Pr Abbassia DEMMOUCHE. Professor in Biology, Biotoxicology laboratory, Department of Biology. Faculty of Naturel Science and life. Djillali Liabes University; Sidi Bel Abbes. Algeria

\section{INTRODUCTION}

Obesity is considered a major health problem(1) is a complex, multifactorial disease that develops from the interaction between genotype and the environment. It is characterized by an excess of adipose tissue (2-3). The most commonly used measurement for determining obesity is the body mass index (BMI), which is calculated as the weight in kilograms divided by the square of height in meters (1).Obesity is linked to human fertility. the effect of obesity on male reproduction has been less well studies than those on female reproduction, but there is growing body of male reproduction (4).The aim of this study was to investigate the impact of body mass index ( BMI )on semen parameters in infertile men.

\section{MATERIEL AND METHODS}

This study included men who attended for infertility evaluation during the period from November 2016 to May 2017, in medically assisted procreation service hospital of $1^{\text {st }}$ November -Oran- west of Algeria .A total of 446 infertile men, the study population was divided into four groups

ISSN: 2250-1177 depending on their BMI , underweight $(<18.5 \mathrm{~kg} /)$, normal weight (18.5-24.99 kg/m2), overweight $25-29.99 \mathrm{~kg} / \mathrm{m} 2)$, and obese $>30.0 \mathrm{~kg} / . \mathrm{semen}$ parameters $(\mathrm{PH}$, volume, concentration, total semen count, vitality, morphology and motility ) were compared across the four BMI groups.

\section{Statical analysis}

The data collected during the research were analyzed using the statistical software (Spss version 22). To report the results we used a descriptive analysis method, calculating the means and standard deviations for the continuous data, the means were then compared using the Student's Test, for the nominal data we calculated the percentages of the different categories .Differences in patient's BMI according to different variables were assessed using the ANOVA test.

We evaluated the impact of the different BMI determined on Semen parameters using the Pearson correlation. The result is reported in form of histograms, sectors and tables. These statistical tests were considered significant if $\mathrm{p}<0.05$. 


\section{RESULTS}

The result showed that ,the most represented age group is $41-50$ years old $(45,1 \%)$ with the means age of $41.91 \pm 6.39$ (years) (Fig. 1).

According to the reason for consultation we found that $78.7 \%$ of our patients have primary infertility. And $21.3 \%$ have secondary infertility (Fig. 2).

The results showed that the mean BMI of infertile men in our study was $29.38 \pm 4.85 \mathrm{Kg} / \mathrm{m} 2$, and the most of patients $45.2 \%$ were obese (Fig. 3).

Table 1 demonstrates the value of semen parameters in studies patients according to their BMI. The results showed that was evidence of an association between BMI and semen parameters (Sperm concentration, Total sperm count, motility, and vitality) and no correlation between Semen volume, morphology and BMI (Table 1).

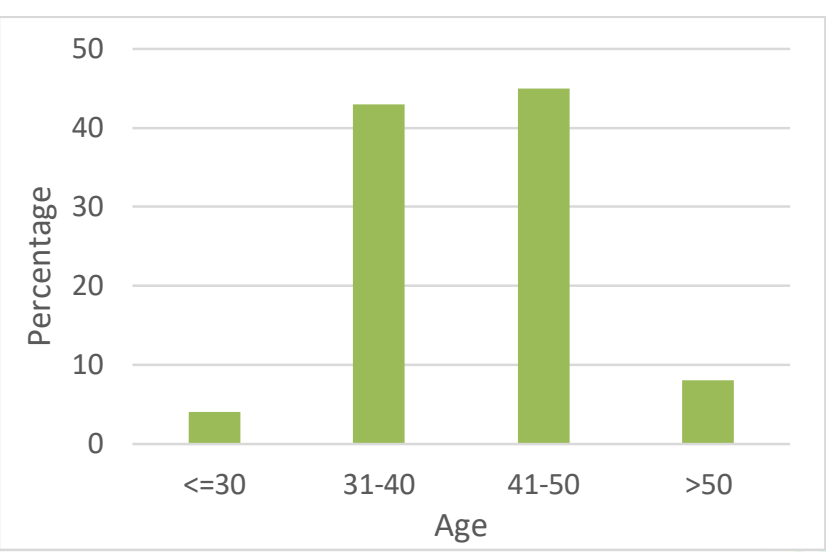

Fig. 1 Frequency distribution for the age of patients

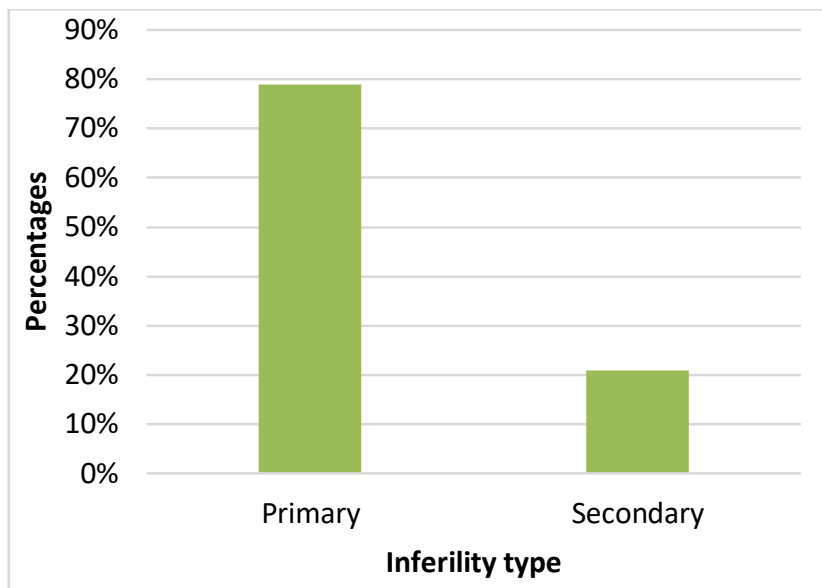

Fig. 2 Distribution of patients by type of infertility

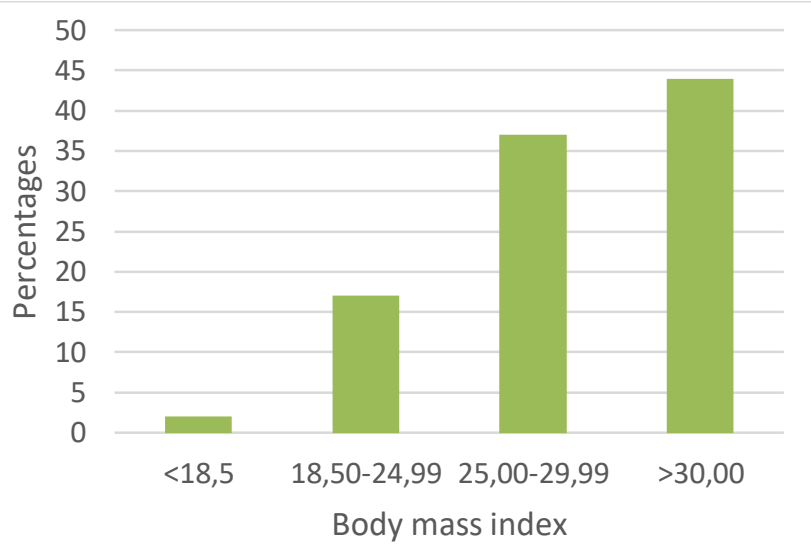

Fig. 3 Frequency distribution for body mass index

Table 1. Semen characteristics compared for males among BMI groups.

\begin{tabular}{|c|c|c|c|c|c|}
\hline \multirow[t]{2}{*}{ Semen parameters } & \multicolumn{4}{|c|}{ BMI groups } & \multirow[t]{2}{*}{$\mathbf{P}$} \\
\hline & $<18.5$ & 18.5-24.99 & $25.00-29.99$ & $>30.00$ & \\
\hline PH & $7,00 \pm 1,41$ & $7,86 \pm, 82$ & $7,88 \pm, 80$ & $7,85 \pm, 81 \pm$ & 0.503 \\
\hline Semen volume & $2,45 \pm, 49$ & $2,97 \pm 1,28$ & $3,11 \pm 1,51$ & $2,98 \pm 1,80$ & 0.824 \\
\hline Sperm concentration & $51,60 \pm 39,32$ & $42,38 \pm 28,18$ & $46,80 \pm 35,49$ & $27,30 \pm 30,46$ & $<0.001$ \\
\hline Total sperm count & $136,14 \pm 121,85$ & $118,95 \pm 92,62$ & $128,38 \pm 107,83$ & $69,11 \pm 81,55$ & $<0.001$ \\
\hline \multicolumn{6}{|l|}{ Sperm motility after 1hour } \\
\hline $\begin{array}{l}\text { Progressive } \\
\text { slow progressive } \\
\text { non progressive } \\
\text { immobile }\end{array}$ & $\begin{array}{l}15,50 \pm 5,1 \\
23,00 \pm 7,07 \\
20,00 \pm 2,00 \\
41,50 \pm 17,68\end{array}$ & $\begin{array}{l}24,71 \pm 4,1 \\
18,79 \pm 10,11 \\
15,90 \pm 1,90 \\
40,76 \pm 20,48\end{array}$ & $\begin{array}{l}24,34 \pm 2,4 \\
19,22 \pm 9,83 \\
15,78 \pm 5,7 \\
40,18 \pm 21,26\end{array}$ & $\begin{array}{l}14,43 \pm 1,43 \\
15,89 \pm 11,51 \\
14,28 \pm 4,8 \\
53,58 \pm 25,09\end{array}$ & $\begin{array}{l}<0.001 \\
0.024 \\
0.274 \\
<0.001\end{array}$ \\
\hline \multicolumn{6}{|l|}{ Sperm motility after 4hour } \\
\hline $\begin{array}{l}\text { Progressive } \\
\text { slow progressive } \\
\text { non progressive } \\
\text { immobile } \\
\end{array}$ & $\begin{array}{l}4,50 \pm, 71 \\
10,73 \pm 2,14 \\
12,55 \pm 9,63 \\
13,20 \pm 9,94\end{array}$ & $\begin{array}{l}14,00 \pm 14,53 \\
10,00 \pm 8,28 \\
14,00 \pm 2,83 \\
71,50 \pm 2,12\end{array}$ & $\begin{array}{l}13,54 \pm 12,07 \\
13,18 \pm 9,33 \\
13,97 \pm 10,19 \\
60,29 \pm 18,22\end{array}$ & $\begin{array}{l}7,25 \pm 10,19 \\
14,32 \pm 10,17 \\
14,25 \pm 9,70 \\
61,71 \pm 53,80 \\
\end{array}$ & $\begin{array}{l}<0.001 \\
0.012 \\
0.204 \\
0.263\end{array}$ \\
\hline \multicolumn{6}{|l|}{ Morphlogy } \\
\hline $\begin{array}{l}\text { Normal } \\
\text { abnormal }\end{array}$ & $\begin{array}{l}16,00 \pm 7,07 \\
84,00 \pm 7,07\end{array}$ & $\begin{array}{l}34,99 \pm 25,74 \\
67,00 \pm 28,33\end{array}$ & $\begin{array}{l}38,03 \pm 27,99 \\
61,89 \pm 27,93\end{array}$ & $\begin{array}{l}33,42 \pm 28,61 \\
65,30 \pm 29,38\end{array}$ & $\begin{array}{l}0.358 \\
0.471\end{array}$ \\
\hline \multicolumn{6}{|l|}{ Vitality } \\
\hline $\begin{array}{l}\text { Spz vivant } \\
\text { Spz mort }\end{array}$ & $\begin{array}{l}64,00 \pm 24,04 \\
36,00 \pm 24,00\end{array}$ & $\begin{array}{l}68,17 \pm 18,49 \\
31,69 \pm 18,63\end{array}$ & $\begin{array}{l}69,74 \pm 19,58 \\
30,26 \pm 19,58\end{array}$ & $\begin{array}{l}56,72 \pm 24,30 \\
42,09 \pm 24,06\end{array}$ & $\begin{array}{l}<0.001 \\
<0.001\end{array}$ \\
\hline
\end{tabular}




\section{DISCUSSION}

Four hundred and forty six males participated in the study, after the subjects were classified into four groups based on BMI. Among 446 infertile men, 02 found with BMI $<18,5$ $\mathrm{kg} / \mathrm{m} 2,72$ with BMI 18.5-24,99 kg/m2, 149 with BMI 25$29,99 \mathrm{~kg} / \mathrm{m} 2$ and 184 were found with $\mathrm{BMI}>30 \mathrm{~kg} / \mathrm{m} 2$. When the mean semen parameter values of each BMI group were compared, our results showed no significant relationship between the BMI and semen volume $(\mathrm{P}=0.824)$. Similar to our results, a metanalysis of 31 relevant studies showed no significant relationship between BMI and semen volume (5).on the other side Chavarro et al. (2010) (6) reported a lower semen volume in obese men. Concerning $\mathrm{PH}$, our results showed no significant relationship between the BMI and $\mathrm{PH}$ semen $(\mathrm{P}=0.503)$.

In our study, sperm concentration and total sperm count in infertile men showed a significant correlation with BMI $(\mathrm{P}<0.001)$. Similar to our results, Jensen et al. (2004) (7) reported a 21.6 and $23.9 \%$ significant reduction in sperm concentration and total sperm count, respectively, in men with BMI $>25$ compared with those classified as normal. Other studies (8-9-10). Reported a negative relationship between sperm count and total count and BMI.

Sperm motility of the study population showed that the mean total motility, progressive and slow progressive grades of motility (after 1hour and 4 hour) were significantly correlation with BMI $(\mathrm{P}<0.001)$ Similar associations were recorded previously (11-12-8-9-10-13). Other studies (14-11) reported a negative relationship between obesity and BMI and sperm motility. Some studies(7-15) failed to report any association between BMI and sperm total motility. Also, MacDonald et al. (2010)(5) in their metanalysis, did not reach a significant correlation between sperm motility and BMI. In addition, our results showed a correlation between immobile grades of motility (after 1hour) and BMI, Similar associations were recorded in nine morbidly obese patients Martini et al. (2010) (15) found a significant increase in the percentage of non-motile spermatozoa $(45.7 \pm 5.5, n=9$ in men with $B M I \geq 40$ vs $33.3 \pm 1.5, n=146$ in men with $30 \leq \mathrm{BMI}<40, \mathrm{P}<0.024$ ).

Concerning Sperm morphology, We did not observe a significant correlation between BMI and sperm morphology. Same results were reported by other studies(16-6-5). However, Hofny et al. (2010)(17) stated a significant positive correlation between BMI and abnormal sperm morphology. Also others studies reported abnormal sperm morphology in obese men (17-18).

Vitality is the percentage of live spermatozoa, the WHO proposes to evaluate this factor when the motility of progressive spermatozoa is less than $40 \%$ (19) ,she finds her interest in measuring mobility because an immobile spermatozoa is not necessarily dead..our results shouwed a significant correlation between vitality and BMI $(\mathrm{P}<0.001)$, (table 2).

Table 2 Research Studies of the Effects of BMI on semen parameters

\begin{tabular}{lll}
\hline Author & Year Published & results/conclusion \\
\hline Hofny et al (17) & $\mathbf{2 0 1 0}$ & BMI had positive correlation with abnormal sperm morphology and negative \\
\hline $\begin{array}{l}\text { Rybar et al (20) } \\
\text { TM Stewart (21) }\end{array}$ & $\mathbf{2 0 1 0}$ & $\begin{array}{l}\text { BMI was not significant in affecting sperm parameters. } \\
\text { There was a significantly lower sperm concentration in obese men, but this was not } \\
\text { accompanied by significant correlations between BMI and any other semen variable. }\end{array}$ \\
\hline $\begin{array}{l}\text { Hammond et al (22) } \\
\text { (23) }\end{array}$ & $\mathbf{2 0 0 8}$ & $\begin{array}{l}\text { associated with low sperm concentration and low motile sperm coun } \\
\text { Overweight had lower sperm count and concentration than normal individuals, but } \\
\text { obese did not show reduction in sperm count surprisingly. None of these differences } \\
\text { were significant. }\end{array}$ \\
\hline Sallmen et al (24) & $\mathbf{2 0 0 6}$ & BMI has a direct negative correlation to sperm \\
\hline
\end{tabular}

\section{CONCLUSION}

The general profile of infertility is polymorphous. The male causes are often multifactorial and are represented by a quantitative and/or a qualitative abnormality of the sperm. In conclusion, this study has found evidence of an association between BMI and semen parameters (Sperm concentration, Total sperm count, motility, and vitality), BMI is a risk factor that influences semen quality and reduces male fertility for that it is suggested to reduce weight in obese males to prevent hormone imbalance which may indirectly lead to sub-fertility.

\section{REFERENCES}

1 WHO. Obesity: preventing and managing the global epidemic. Report of a WHO consultation. 2000; World Health Organ Tech Rep Ser 894:i-xii, 1-253.
2 Kopelman P.G. Obesity as A Medical Problem. 2000; Nature 2000; 404(6778): 43635.

3 Kantachuvessiri A. Obesity in Thailand. The Journal of Medical Association of Thailand. 2005; 88(4):554-560.

4 Filer R.B. Obesity and Reproduction. The Journal of Lancaster General Hospital ;Reproductive Endocrinology; The Fertility Center . 2009; 4(4):134-135.

5 MacDonald AA, Herbison GP, Showell M, Farquhar CM. The impact of body mass index on semen parameters and reproductive hormones in human males: a systematic review with meta-analysis. Hum Reprod Update. 2010; 16:293-311

6 Chavaro.J.E,Toth,T.L.,Wright,D.L.,Meeker,J.D,Hauser,R. Body mass index in relation to semen quality,sperm DNA integrity,and serum reproduction hormone levels among men attending an infertility. clinic.fertility and sterility. 2010; 93:2222-2235.

7 Jensen T.K., Andersson A.M., Jorgensen N., Andersen A.G., Carlsen E., Petersen J.H. and Skakkeb aek N.E. Body Mass Index in 
Relation to Semen Quality and Reproductive Hormones Among 1,558 Danish Men. Fertility and Sterility. 2004; 82(4):863-870.

8 Hammoud A.O., Wilde N., Gibson M., Parks A., Carrell D.T. and Meikle A.W. Male Obesity and Alteration in Sperm Parameters. Fertility and Sterility. 2008; 90(6):2222-2225.

9 Martini A.C., Molina R.I., Ruiz R.D. and Fiol de Cuneo M. Obesity and male fertility, Review Rev Fac Cien Med Univ Nac Cordoba. 2012; 69(2): 102110

10 Braga D.P., Halpern G., Figueira Rde C., Setti A.S., Iaconelli A. Jr. Borges E. Jr. Food Intake and Social Habits in Male Patients and Its Relationship to Intracytoplasmic Sperm Injection Outcomes. Fertility and Sterility. 2012; 97(1):53-59.

11 Kort H.I., Massey J.B, Elsner C.W., Mitchell-Leef D., Shapiro D.B, Witt M.A. and Roudebush W.E. Impact of Body Mass Index Values on Sperm Quantity and Quality. Reproductive Biology Associates, 1150 Lake Hearn Drive, Suite 400, Atlanta, GA 30342 , USA. 2006; 27(3):450-452.

12 Qin D.D., Yuan W., Zhou W.J., Cui Y.Q., Wu J.Q. and Gao E.S. Do Reproductive Hormones Explain The Association Between Body Mass Index and Semen Qquality? Asian Journal of Andrology. 2007; 9(6):827-834.

13 Sermondade N., Faure C., Fezeu L., Levy R. and Czernichow S. Obesity-Fertility Collaborative Group. Obesity and Increased Risk for Oligozoospermia and Azoospermia. International Medicin. 2012; 172(5):440442.

14 Fejes I, Koloszar S, Zavaczki Z, Daru J, Szollosi J, Pal A. Effect of body weight on testosterone/estradiol ratio in oligozoospermic patients. Arch Androl. 2006; 52:97-102.

15 Martini AC, Tissera A, Estofan D, Molina RI, Mangeaud A, de Cuneo MF, Ruiz RD. Overweight and seminal quality: a study of 794 patients. Fertil Steril. 2006; 94:1739-1743.
16 Hammoud AO, Gibson M, Peterson CM, Meikle AW, Carrell DT. Impact of male obesity on infertility: a critical review of the current literature. Fertil Steril. 2008; 90:897-904.

17 Hofny ER, Ali ME, Abdel-Hafez HZ, Kamal Eel D, Mohamed EE, Abd El-Azeem HG, Mostafa T. Semen parameters and hormonal profile in obese fertile and infertile males. Fertil Steril. 2008; 94:581-584.

18 Hakonsen L.B., Thulstrup A.M., Aggerholm A.S., Olsen J., Bonde J.P., Andersen C.Y., Bungum M., Ernst E.H., Hansen M.L., Ernst E.H. and Ramlau-Hansen C.H. Does Weight Loss Improve Semen Quality and Reproductive Hormones? Results from a cohort of severely obese men. Danish Ramazzini Center Reprod Health. 2011; 17(8):1-24.

19 World Health Organization (WHO). The International Programm on Chemical Safety (IPCS), Global assessment of the state-of-the-science of endocrine disruptors. 2002.

20 Rybar R, V Kopecka. Male obesity and age in relationship to semen parameters and sperm chromatin integrity. Andrologia. 2011; 43(4):286-291.

21 Stewart TM, DY Liu. Associations between andrological measures, hormones and semen quality in fertile Australian men: inverse relationship between obesity and sperm output. Hum Reprod. 2009; 24(7):1561-1568.

22 Hammoud AO, M Gibson. Impact of male obesity on infertility: a critical review of the current literature. Fertil Steril. 2008; 90(4):897-904.

23 Aggerholm AS, AM Thulstrup. Is overweight a risk factor for reduced semen quality and altered serum sex hormone profile? Fertil Steril. 2008; 90(3):619-626

24 Sallmen M, DP Sandler. Reduced fertility among overweight and obese men. Epidemiology. 2006; 17(5):520-523. 